\title{
Profile of Students' Mathematical Creative Thinking Ability in Solving Mathematical Problem
}

\author{
Putri Daiana $^{(1, *)}$, Surahmat ${ }^{2}$, Abdul Halim Fathani ${ }^{(3)}$ \\ ${ }^{1,2,3}$ Program Studi Pendidikan Matematika, FKIP, Universitas Islam Malang \\ Jalan Mayjen Haryono 193 Malang, Indonesia \\ ${ }^{1}$ Program Studi Magister Pendidikan Matematika, FMIPA, Universitas Negeri Malang \\ Jalan Semarang 5 Malang, Indonesia
}

Received: November 09, 2020

Revised: February 05, 2021

Accepted: February 09, 2021

\begin{abstract}
Mathematical creative thinking ability has an important position in solving mathematical problems so this study was aimed to describe the diversity of students' creative thinking abilities. It is in accordance with the fact in the field that was indicated by the score of two of the students which were over 70. So that it has an impact on the learning outcomes of students that are not optimal yet. And the objective of the research was to determine the profile of students' mathematical creative thinking ability in solving mathematical problem. This research used descriptive qualitative research design.The data collection technique was in the form of a written test. Based on the results of the analysis, it can be concluded that: (1) MAS subject was included in the very creative category (TKBK 4) which the subject was able to meet all indicators, namely fluency, flexibility and novelty; (2) the MAPS subject was included in the creative category (TKBK 3) in which the subject was able to meet two indicators, namely fluency and flexibility; (3) ASA subjects fell into the fairly creative category (TKBK 2) in which the subject was able to meet one indicator, namely flexibility; (4) the FNA subject was included in the less creative category (TKBK 1) in which the subject only met the indicators of fluency; (5) ANS subject was included in the uncreative category (TKBK 0 ) in which the subject is not able to meet all indicators, namely fluency, flexibility and novelty.
\end{abstract}

Keywords: ability, creative thinking, mathematical problems

(*) Corresponding Author:

putri.daiana77@gmail.com Phone Number: (+62)82123468640

How to Cite: Daiana, P., Surahmat, S., \& Fathani, A.H. (2021). Profile of students' mathematical creative thinking ability in solving mathematical problem. Formatif: Jurnal Ilmiah Pendidikan MIPA, 11 (1): 49-62. http://dx.doi.org/10.30998/formatif.v11i1.7810

\section{INTRODUCTION}

Curriculum 2013 stated that education aims to prepare everyone to have the productive, creative, innovative and effective ability (Sari et al, 2017). This shows that thinking is a heavy demand in this era of technological development. And one of the abilities in thinking is creative thinking, since in modern life like nowadays, the complexity level of the problem is higher, therefore creative thinking is very important in global competition like today (Maharani, 2014). If someone is trained in creative thinking ability, it will be easier for them to solve problems in various ways they can do in real life. And commonly, students who are very creative have academic achievement which are above average, but do not have to be top students (Humble et al, 2018; Mpofu et al, 2006).

Çetinkaya (2014) \& Kashefi et al (2012) stated that creativity must be sensitive to a problem, an information and determine the difficulty of finding a solution to a problem. 
Santoso et al (2014) argued Thar the ability to think creatively in mathematics is the ability to provoke students' thinking in finding a variety of solutions.

Therefore, in (Švecová et al, 2014) stated that creative thinking can be developed with a creative teacher so that it can help forming creative situations, fostering student initiative in fostering new ideas. This agrees with (Soleymanpour, 2014). that teacher creativity can significantly influence student achievement.

According to (Polya, 2004), the important thing in solving problems is the idea of compiling a solution plan. Therefore, creative thinking is more often indicated by problem solving, because in creative thinking, it will balance the two parts of the brain, namely the balance between logic and intuition. If someone has the ability to think creatively, they will find it easier to solve problems in various ways both problems in real life or in mathematics. The researchers concluded that one of the ways to identify people who think creatively is they tend to have a high sense of wanting to know something, rich on ideas, and selfconfidence. If the students have a lot of ideas, it will be easier for the students in solving problems (Hendriana et al, 2017; Piawa, 2010; Binta Briliantyas et al, 2018; Baum \& Newbill, 2010; Sa'dijah, 2013).

According to Sitorus \& Masrayati (2016) in cultivating creative potential in students, encouragement by the social environment is necessary. Therefore, the ability to mathematical creative thinking will be easier and evolving maximally if applied in a process of learning by teachers that exist in schools periodically. Because teaching and learning is a complex activity in fostering student creativity (Saefudin, 2012). But most teachers in the process of learning in the classroom paid minimal attention to students' mathematical creative thinking ability. Then the case is going to impact the students who find difficulty in finding or pulling out the creative ideas and less able to convey their thoughts. (Sriraman, 2005); (Mann, 2006); (Lev-Zamir \& Leikin, 2011).

With regard to TKBK, there are several studies, including: (Partia Iswanti \& Riyadi, 2016) giving results that the type of visual learning style has TKBK4 (very creative) in solving geometric problems, because students have aspects of fluency, flexibility, aspects of novelty. And the type of auditory learning style has TKBK 3 (creative) in solving geometric problems, because students have aspects of fluency and flexibility. Types of kinesthetic learning styles have TKBK 2 (quite creative) and TKBK 1 (less creative), because some students have aspects of flexibility and fluency aspects.

According to (Yuli \& Siswono, 2018) the characteristics of the level of creative thinking through problem solving and problem-posing consist of five levels, namely level 4 (very creative), level 3 (creative), level 2 (fairly creative), level 1 (less creative), and level 0 (uncreative). In (Siswono, 2006) each of these levels have different backgrounds and abilities and also know the characteristics of each level in the ability to think creatively.

And for indicators of creative thinking that is according to (Silver, 1997) expressed creativity in solving a problem is indicated by fluency, flexibility, and novelty. So, based on that, it can be created table of correlation between the ability of creative thinking in solving (Table 1).

According to (Prianggono, 2010) currently students are at the creative thinking ability level 0 (uncreative) in solving mathematical problems in general, so that students' learning outcomes are still not optimal. Because they tend to memorize formulas and solve the problem in accordance with the teachers example so that students feel difficulty in finding or pulling out their creative ideas whereas in solving the problem also requires thinking to create ideas that are new in order to find a solution which is unusual (Huljannah et al., 2018). 
Table 1. Correlation of Creative Thinking Ability Levels (TKBK) in Solving Straight Line Equation Problems

\begin{tabular}{lll}
\hline No & TKBK aspects & \multicolumn{1}{c}{ Criteria } \\
\hline 1 & Fluency & $\begin{array}{l}\text { Students were able to resolve the matter of the straight-line } \\
\text { equation fluently and correctly } \\
\text { Students can complete in some various ways and the } \\
\text { completion of which vary in solving the problem } \\
\text { Students were able to resolve the matter of the straight-line } \\
\text { equation with language, manner or his own. }\end{array}$ \\
\hline
\end{tabular}

Other factors resulting in inhibition of the students in the ability of mathematical creative thinking is the process of learning that usually impressed one direction (teacher centered) students just listen, record and memorize what were described by teachers. So, the objective of this research was to describe the profile of students' mathematical creative thinking in solving mathematical problems on the straight-line equation material class VIIIC of SMP Wahid Hasyim Malang.

\section{METHODS}

The type of research that is used in this research was descriptive qualitative research which is research that uses the data of qualitative and describes to produce a clear and detailed description about the degree of student's creative thinking ability on the straight-line equation material. This research was conducted at SMP Wahid Hasyim Malang.

Subject used in this qualitative study were 5 learners who represent each level of the ability to think which were very creative, creative, fairly creative, less creative, and un creative. For taking the subject is based on indicators of creative thinking abilities that pay attention to aspects of fluency, flexibility, and novelty, this is in accordance with the formulation of the level of creative thinking skills in mathematics by (Siswono, 2008).

Table 2. Research Subjects

\begin{tabular}{lcl}
\hline Subject & Name & \multicolumn{1}{c}{$\begin{array}{c}\text { Level of Creative } \\
\text { Thinking Ability (TKBK) }\end{array}$} \\
\hline Subject 1 & (MAS) & Very Creative (TKBK 4) \\
Subject 2 & (MAPS) & Creative (TKBK 3) \\
Subject 3 & (ASA) & Fairly Creative (TKBK 2) \\
Subject 4 & (FNA) & Less Creative (TKBK 1) \\
Subject 5 & (ANS) & Uncreative (TKBK 0) \\
\hline
\end{tabular}

The presentation of the data carried out by the researcher, namely classifying and describing the profiles of three main criteria for creative thinking, namely fluency, flexibility and novelty. Students were categorized at the level of creative thinking ability which consists of five levels, namely very creative, creative, fairly creative, less creative, and uncreative. Finally, draw conclusion or verification to describe the level of creative thinking skills in each group based on data presentation. 


\section{RESULTS \& DISCUSSION}

\section{Results}

\section{a) Profile of Subject MAS with Creative Thinking Ability Level (TKBK 4)}

Subject MAS were included in the level of creative thinking ability level 4 (very creative), this was proved by the results of the test, the subject has fulfilled the three indicators of thinking ability, namely fluency, flexibility and novelty as seen in Figure 1 , the subject MAS was said to understand the problem by writing what is known and asked so that it was able to solve problems smoothly and coherently and the subject MAS can also draw in Cartesian coordinates according to the calculation accurately. This shows that the fluency indicator can be shown by the subject MAS where the subject was able to solve straight line equation problems smoothly and correctly.

\section{Answer Number 1 From the TKBK 4 Subject}

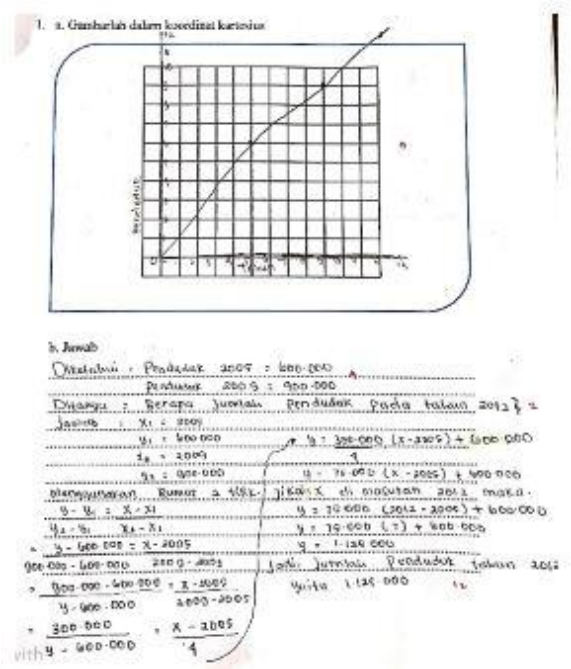

Figure 1. Answer Number 1 From the TKBK 4 Subject

\section{Answer Number 2 From the TKBK 4 Subject}

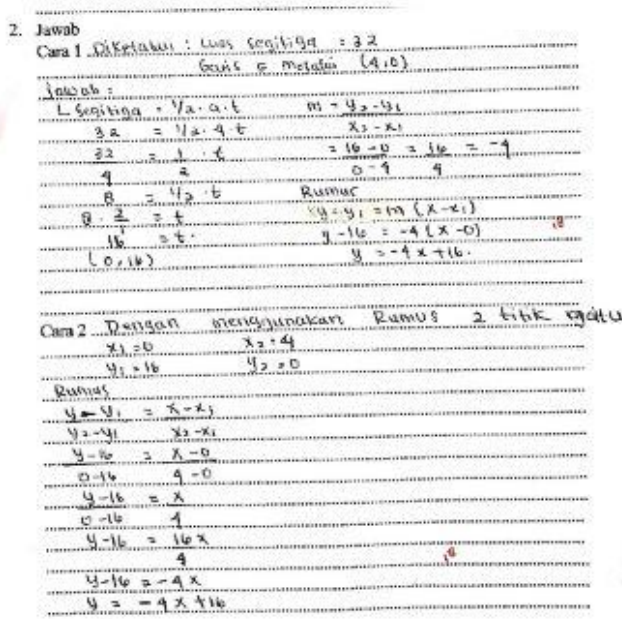

Figure 2. Answer Number 2 From the TKBK 4 Subject 


\section{Answer Number 3 From the TKBK 4 Subject}

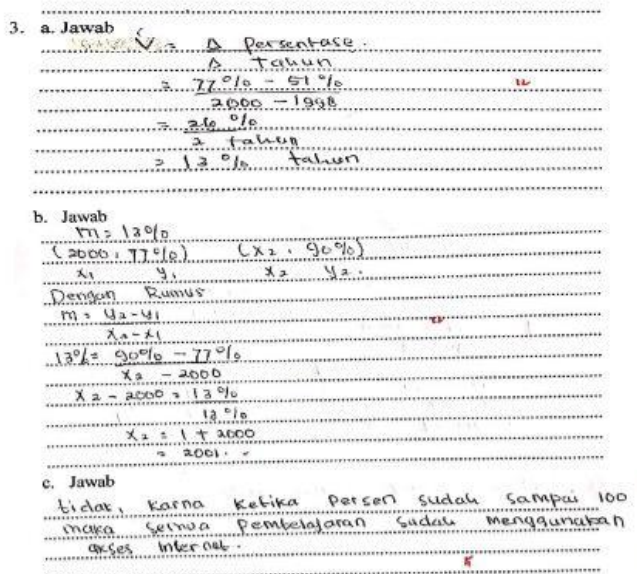

Figure 3. Answer Number 3 From the TKBK 4 Subject

Subject MAS were also able to provide different answers in solving problems, as shown in Figure 2. Subject MAS were able to solve with different answers and can solve the equation for line $\mathrm{g}$ with different formulas, namely using the 1-point formula and using the 2-point formula. This shows that the Subject MAS is able to show flexibility in itself, where the Subject MAS was able to solve the equation for line $\mathrm{g}$ in another way from a previously known point.

Subject MAS were also able to provide a new answer as shown in Figure 3, Subject MAS were able to show different patterns from other subjects and able to answer various problems. Based on this, it shows that the indicator of novelty was able to be shown by Subject MAS by being able to provide new and different answers than in general.

\section{b) Profile of Subject MAPS with Creative Thinking Ability Levels (TKBK 3)}

Subjects that were included in the level of creative thinking ability level 3 (creative), showed that the subject is able to achieve two indicators of creative thinking abilities, namely fluency and flexibility. As seen in Figure 4, the Subject MAPS was able to solve problems smoothly even though it was not too coherent and the Subject MAPS can draw in Cartesian coordinates according to the calculation precisely.

\section{Answer Number 1 From the TKBK 3 Subject}

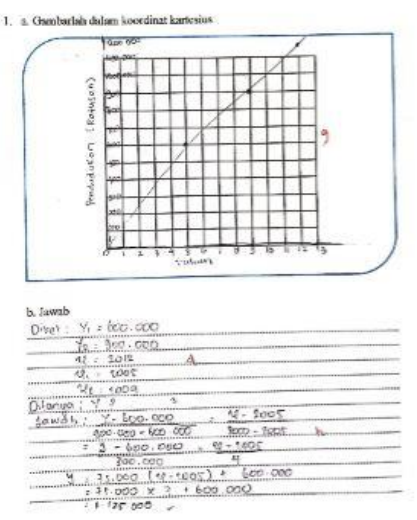

Figure 4. Answer Number 1 From the TKBK 3 Subject 


\section{Answer Number 2 From the TKBK 3 Subject}

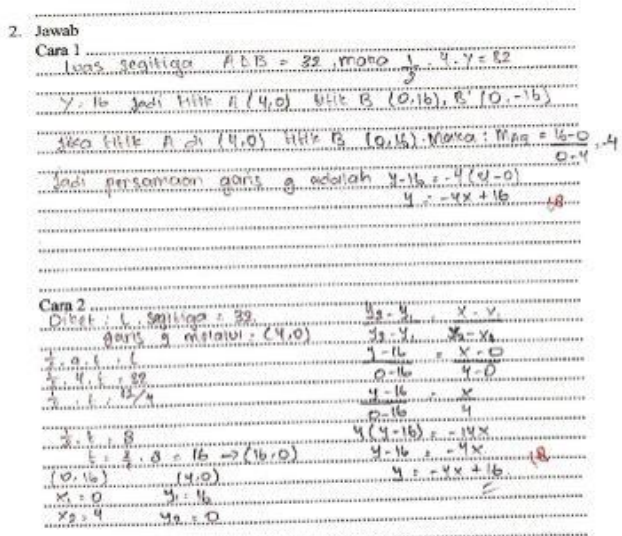

Figure 5. Answer Number 2 From the TKBK 3 Subject
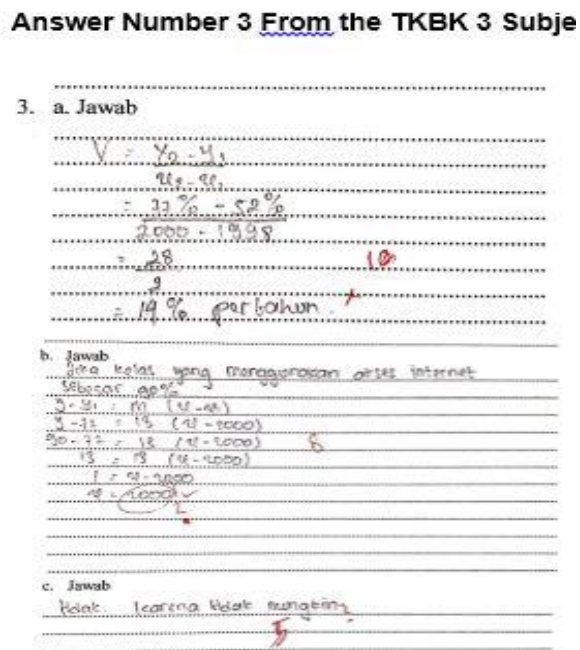

Figure 6. Answer Number 3 the From TKBK 3 Subject

The Subject MAPS was also able to show flexibility in itself, as seen in Figure 5. The Subject MAPS was able to solve more than one way with the same answer and also solve the line g equation using the 1-point formula and using the 2-point formula. This shows that the Subject MAPS was able to show flexibility in himself.

It was just that the Subject MAPS has not been able to provide something different or new, as seen in Figure 6, the subject was able to answer all but with the usual pattern and the subject gives the wrong answer.

\section{c) Profile of Subject ASA with Creative Thinking Ability Levels 2}

Subject that fall into the category of creative thinking ability level (TKBK) 2 (creative enough), show that the subject was able to show one indicator of creative thinking abilities, namely flexibility. Subject ASA were able to provide good answers, as seen in Figure 7, where the same as Subject MAS, and Subject MAPS were able to solve more than one different solution, and can also use other ways to solve the line $g$ equation. But the subject in method 1 calculates the $\mathrm{y}$ axis at point $\mathrm{B}(0, \mathrm{y})$ and also $\mathrm{B}^{\prime}$ $(0,-y)$ which means the length of $\mathrm{OB}=\mathrm{OB}^{\prime}$. This shows that the Subject ASA achieved the flexibility indicator. 


\section{Answer Number 2 From the TKBK 2 Subject}

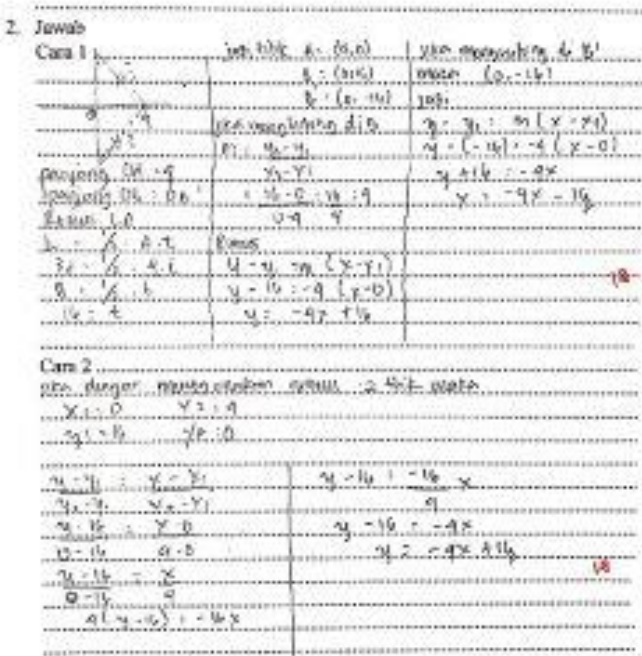

Figure 7. Answer Number 2 From the TKBK 2 Subject

\section{Answer Number 1 From the TKBK 2 Subject}

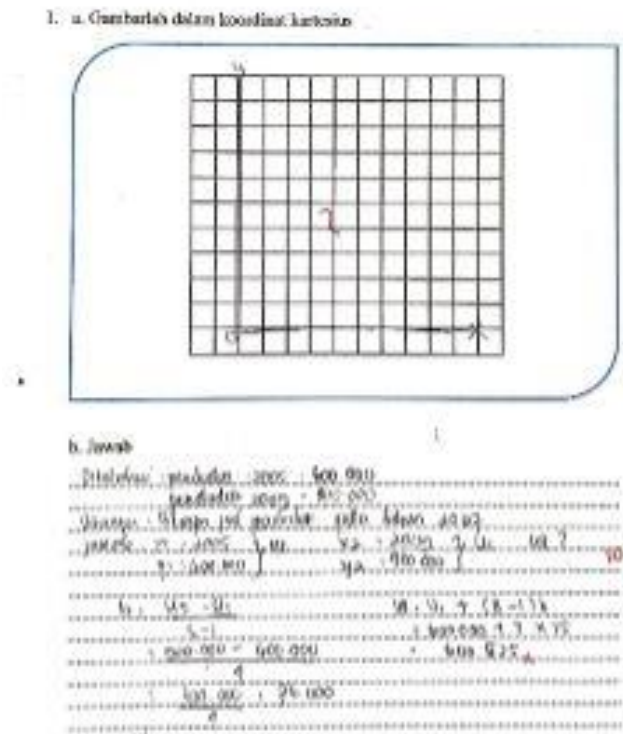

Figure 8. Answer Number 1 From the TKBK 2 Subject

The Subject ASA was still unable to complete the novelty indicators as shown in Figure 8, the Subject ASA still cannot solve the problem with the correct answer and cannot draw and also perform calculations correctly and the Subject ASA did not understand the problems given by the teacher.

The Subject ASA also still cannot fulfill the novelty indicator because the subject ASA cannot answer and finish properly as shown in Figure 9 below. 


\section{Answer Number 3 From the TKBK 2 Subject}

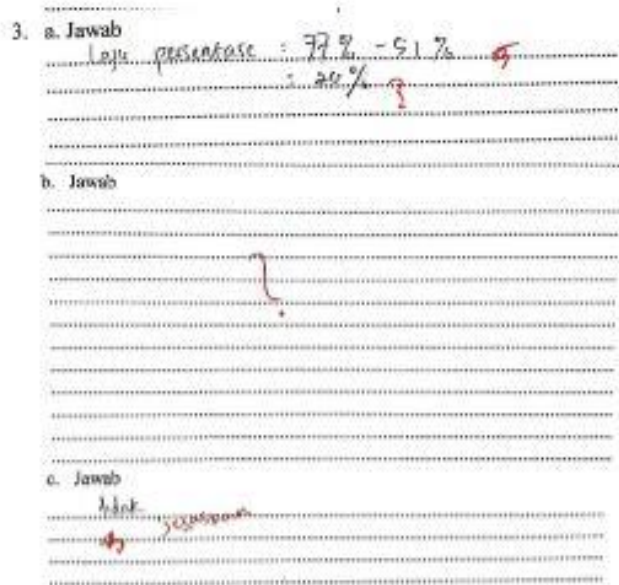

Figure 9. Answer Number 3 From the TKBK 2 Subject

\section{d) Profile of Subject FNA with Creative Thinking Ability Levels 1}

Subject that fall into the category of creative thinking ability level (TKBK) 1 (less creative), show that the subject was only able to show one indicator of creative thinking ability, namely fluency. Subject FNA were able to provide good answers, as seen in Figure 10, Subject FNA were able to understand problems by writing what they know, solve problems correctly and smoothly and also Subject FNA can also draw Cartesian coordinates correctly.

\section{Answer Number 1 From the TKBK 1 Subject}

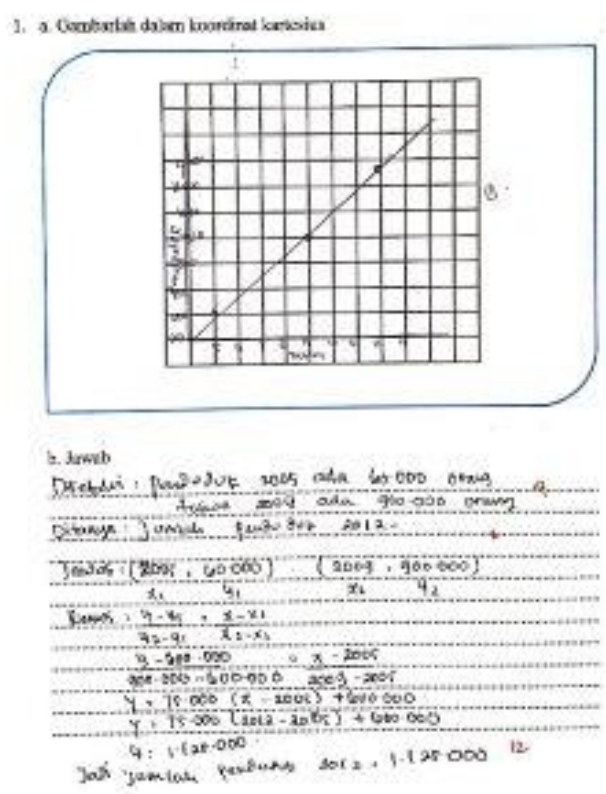

Figure 10. Answer Number 1 From the Subject TKBK 1 


\section{Answer Number 2 From the TKBK 1 subject}

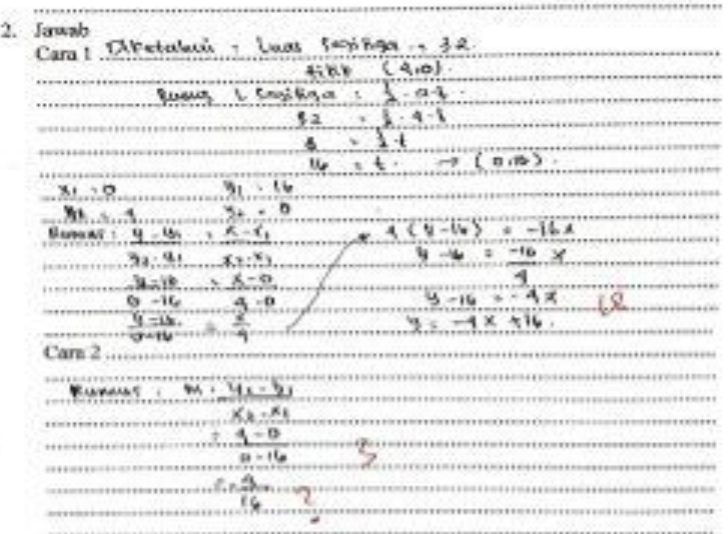

Figure 11. Answer Number 2 From the TKBK 1 Subject

\section{Answer Number 3 From the TKBK 1 Subject}

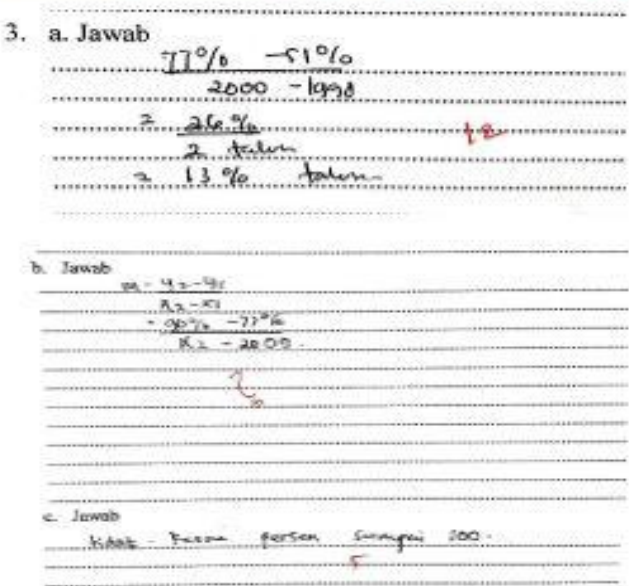

Figure 12. Answer Number 3 From the TKBK 1 Subject

The Subject FNA has not been able to complete the flexibility indicator as shown in Figure 11, the subject felt it was difficult to complete more than one way. The Subject FNA was able to complete more than one solution but method 2 was wrong so that it was only able to complete with one solution.

Similar to the flexibility indicator, the Subject FNA was still unable to reach the novelty indicator shown in Figure 12 because the subject was still unable to answer various solutions and was less able to understand the problem.

\section{e) Profile of Subject ANS with Creative Thinking Ability Levels 0}

Subjects included in the category of creative thinking ability level (TKBK) 0 (uncreative), indicating that the subject has not been able to bring up the three indicators of creative thinking abilities as shown in Figure 13. Subject ANS on the fluency indicator were able to answer but there were errors and cannot draw in Cartesian coordinates correctly. 


\section{Answer Number 1 From the TKBK 0 Subjes}

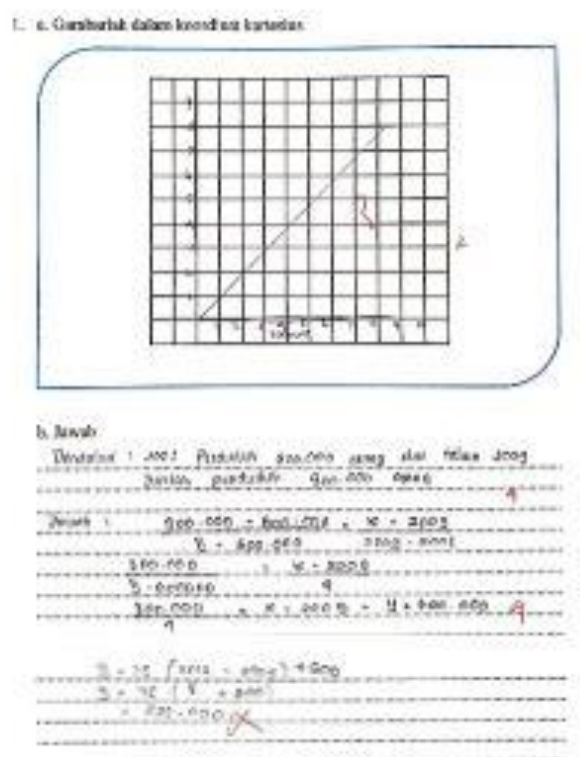

Figure 13 Answer Number 1 From the Subject TKBK 0

\section{Answer Number 2 Erom the TKBK 0 Subject}

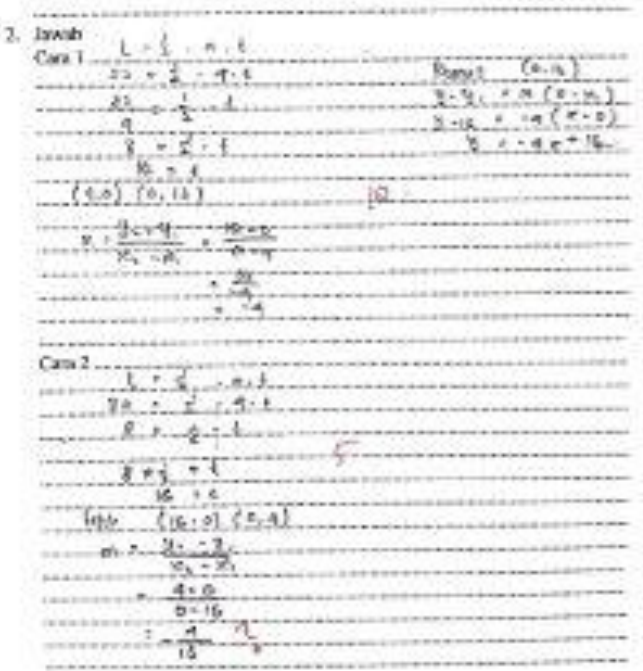

Figure 14 Answer Number 2 From the TKBK 0 Subject 


\section{Answer Number 3 From the TKBK 0 Subject}

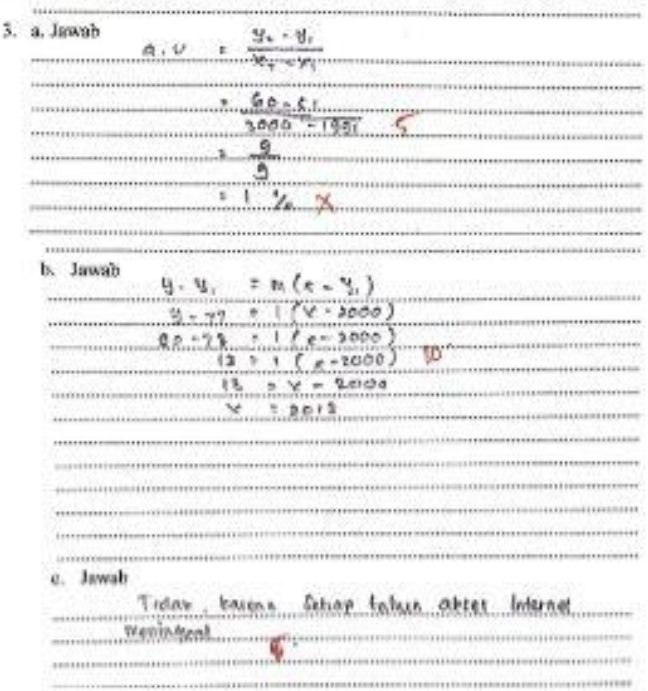

Figure 15 Answer Number 3 From Subject TKBK 0

Subject ANS have not been able to complete the flexibility indicators as shown in Figure 14, the subject felt it was difficult to complete more than one way. Subject ANS solved in more than one way but there were errors and the subject only understood one formula

Similarly, the Subject ANS flexibility indicator was still unable to reach the novelty indicator shown in Figure 15 because the subject was solving problems with the wrong settlement pattern.

\section{Discussion}

From the analysis of research on every subject above, the researchers have discovered some findings of which are: 1) every student has different creative thinking ability. 2) most student were able to resolve the matter with the fluency that the students were able to resolve the matter of the straight-line equation fluently and correctly. 3) students who were able to complete several problems in the homogeneous process. 4) The most of students were looking at a matter in a less thorough and careful way.

At level 4 (very creative) students were able to resolve the problems fluency and coherently and able to give an answer that was more than one way that was different and also created a pattern that was different or new. Students at level 4 tends not to experience difficulties in answering.

At level 3 (creative) participant students were able to resolve the problems fluently but not too coherently and able to give an answer that was more than one way that was different and formulas were different but less precise in completing the pattern which was different or new. Participants learners at level 3 tends to complete the problem of patterns which were different or new less thoroughly.

At level 2 (fairly creative) students were less understood problem so they were not able to resolve the problems with the right answer and less precise in completing the different or new pattern but was able to give an answer that was more than one way with different formula. Students at level 2 tends to less understood the problem in the form of fluency and novelty. 
At level 1 (less creative) students were able to resolve the problems fluently and coherently and able to answer more than one way that was different but it was less precise and less understood the problem in completing the pattern was a pattern that was different or new. Students tended to less understand the problem in answering that in more than one different way. Level 1 students were inclined less understand the problem in the form of flexibility and novelty.

At level 0 (uncreative) students have not been able to understand and resolve problems fluently and coherently and have not been able to give an answer that is more than one way that was different and also create a pattern that was different or new. So, the students at level 0 mostly feel difficult in completing the problem.

This is in line with the results of research (Partia Iswanti \& Riyadi, 2016) which states that the visual learning style type has TKBK4 (very creative) in solving geometric problems, because students have aspects of fluency, flexibility and have aspects of fluency, flexibility, novelty. with the type of auditory learning style has TKBK 3 (creative) in solving geometric problems, because students have aspects of fluency and flexibility. type of kinesthetic learning style has TKBK 2 (quite creative) and TKBK 1 (less creative), because some students have aspects of flexibility and have fluency aspects. The similarity in this study is both to analyze the level of creative thinking skills, while the difference is in the reviews and students.

In line with the opinion (Siswono, 2008) suggested two assumptions in thinking creatively that is the first of each person have creative in degrees specified by certain way. The second was the ability to think creatively on a person can be learned and honed so that the creativity of every person has different degrees and have a way of its own to realize their creativity. So Amabile also explained that someone may have ability degree to produce works that new and appropriate fields so that they can be said to be more or less creative.

So it can be concluded that the creative thinking process which represents the level of the ability to think creatively has different characters in showing every indicator of the ability to think creatively, namely the Subject MAS profile was included in the TKBK 4 category (very creative) where the subject was able to fulfill all indicators, namely fluency, flexibility. and novelty in solving problems and the subject profile of MAPS was included in the TKBK 3 (creative) category where the subject was able to meet two indicators, namely fluency and flexibility, the Subject ASA profile was included in the TKBK 2 category (fairly creative) where the subject was able to fulfill one indicator, namely flexibility, the profile of the Subject FNA was included in the TKBK 1 category (less creative) where the subject only meets the indicators of fluency and the Subject ANS profile was included in the TKBK 0 category (uncreative) where the subject was unable to meet all indicators, namely fluency, flexibility and novelty.

\section{CONCLUSION}

Based on the above discussion, it can be concluded that for the very creative category the subject was able to meet all indicators, namely fluency, flexibility and novelty in solving problems and in the creative category profile the subject was able to fulfill two indicators, namely fluency and flexibility, the category profile of fairly creative fulfilled one indicator, namely flexibility. The profile in the less creative category of the subject only meets the indicators of fluency and in the uncreative category profile the subject was not able to meet all the indicators, namely fluency, flexibility and novelty. 


\section{REFERENCES}

Baum, B. L. M., \& Newbill, P. L. (2010). Instructional design as critical and creative thinking. TechTrends, 54 (5), 27-37.

Binta Briliantyas, B., Kriswandani, K., \& Ratu, N. (2018). Analisis tingkat kemampuan berpikir kreatif siswa dalam menyelesaikan masalah open-ended pada materi bangun datar bagi siswa kelas VIII SMP Kristen 02 Salatiga. Pendekar: Jurnal Pendidikan Berkarakter, 1(1), 6. https://doi.org/10.31764/pendekar.v1i1.244

Çetinkaya, Ç. (2014). The effect of gifted students' creative problem solving program on creative thinking. Procedia - Social and Behavioral Sciences, 116(1974), 3722-3726. https://doi.org/10.1016/j.sbspro.2014.01.830

Hendriana, H., Rohaeti, E. E., \& Sumarmo, U. (2017). Hard Skills dan Soft Skills Matematik Siswa. Bandung: Refika Aditama.

Huljannah, M., Sa'dijah, C., \& Abd.Qohar2. (2018). Profil berpikir kreatif matematis mahasiswa pendidikan guru sekolah dasar. Jurnal Pendidikan: Teori, Penelitian, Dan Pengembangan, 3(11), 1428-1433.

Humble, S., Dixon, P., \& Mpofu, E. (2018). Factor structure of the torrance tests of creative thinking figural form a in kiswahili speaking children: multidimensionality and influences on creative behavior. Thinking Skills and Creativity, 27, 33-44. https://doi.org/10.1016/j.tsc.2017.11.005

Kashefi, H., Ismail, Z., \& Yusof, Y. M. (2012). Supporting engineering students' thinking and creative problem solving through blended learning. Procedia - Social and Behavioral Sciences, 56, 117-125. https://doi.org/10.1016/j.sbspro.2012.09.638

Lev-Zamir, H., \& Leikin, R. (2011). Creative mathematics teaching in the eye of the beholder: Focusing on teachers' conceptions. Research in Mathematics Education, 13(1), 17-32.

Maharani, H. R. (2014). Creative thinking in mathematics: are we able to solve mathematical problems in a variety of way? International Conference on Mathematics, Science, and Education 2014.

Mann, E. L. (2006). Creativity: The essence of mathematics. Journal for the Education of the Gifted, 30(2), 236-260. https://doi.org/10.4219/jeg-2006-264

Mpofu, E., Myambo, K., Mogaji, A. A., Mashego, T.-A., \& Khaleefa, O. H. (2006). African perspectives on creativity. The International Handbook of Creativity, 465.

Partia Iswanti, Riyadi, B. U. (2016). Analisis tingkat kemampuan berfikir kreatif peserta didik dalam memecahkan masalah geometri ditinjau dari gaya belajar kelas $\mathrm{x}$ matematika ilmu alam. (MIA) 4 SMA Negeri 2 Sragen, tahun pelajaran 2014/2015. Jurnal Elektronik Pembelajaran Matematika, 4(6), 632-640.

Piawa, C. Y. (2010). Building a test to assess creative and critical thinking simultaneously. Procedia - Social and Behavioral Sciences, 2(2), 551-559. https://doi.org/10.1016/j.sbspro.2010.03.062

Polya, G. (2004). How to solve it: A new aspect of mathematical method (Vol. 85). Princeton University Press.

Prianggono, A. (2010). Analisis proses berpikir kreatif siswa sekolah menengah kejururuan ( smk) dalam pemecahan dan pengajuan masalah. 133-142.

Sa'dijah, C. (2013). Kepekaan bilangan siswa SMP melalui pembelajaran matematika kontekstual yang mengintegrasikan keterampilan berpikir kreatif. Jurnal Pendidikan dan Pembelajaran Universitas Negeri Malang, 20(2), 222-227. 
Saefudin, A. A. (2012). Pengembangan kemampuan berpikir kreatif siswa dalam pembelajaran matematika dengan pendekatan pendidikan matematika realistik Indonesia (pmri). Al-Bidiiyah, Vol/4 No.

Santoso, H. R. W., Ratu, N., \& Yunianta, T. N. H. (2014). Deskripsi tingkat kemampuan berpikir kreatif (tkbk)pada materi segiempat siswa kelas VII SMP Negeri 1 Pabelan $\begin{array}{lllll}\text { Kabupaten } & \text { Semarang. } & \text { Satya }\end{array}$ https://doi.org/10.24246/j.sw.2014.v30.i2.p82-95

Sari, A. P., Ikhsan, M., \& Saminan, S. (2017). Proses berpikir kreatif siswa dalam memecahkan masalah matematika berdasarkan model wallas. Beta Jurnal Tadris Matematika, 10(1), 18. https://doi.org/10.20414/betajtm.v10i1.102

Schindler, M., \& Lilienthal, A. J. (2020). Students' creative process in mathematics: insights from eye-tracking-stimulated recall interview on students' work on multiple solution tasks. International Journal of Science and Mathematics Education, 18(8), 1565-1586. https://doi.org/10.1007/s10763-019-10033-0

Silver, E. A. (1997). Fostering creativity through instruction rich in mathematical problem solving and problem posing. Zdm, 29(3), 75-80. https://doi.org/10.1007/s11858-9970003-X

Siswono. (2006). Proses berpikir kreatif siswa dalam memecahkan dan mengajukan masalah matematika. Jurnal Ilmu Pendidikan, 1-14.

Siswono, T. Y. E. (2008). Model pembelajaran matematika berbasis pengajuan dan pemecahan masalah untuk meningkatkan kemampuan berpikir kreatif. Surabaya: Unesa university press.

Sitorus, J., \& Masrayati. (2016). Students' creative thinking process stages: implementation of realistic mathematics education. Thinking Skills and Creativity, 22, 111-120. https://doi.org/10.1016/j.tsc.2016.09.007

Soleymanpour, J. (2014). The effects of creative teaching method on motivation and academic achievement of elementary school students in academic year $2014-2015$. Singaporean Journal of Business , Economics and Management Studies, 3(5), 35-39. https://doi.org/10.12816/0010957s

Sriraman, B. (2005). Are giftedness and creativity synonyms in mathematics? Journal of Secondary Gifted Education, 17(1), 20-36. https://doi.org/10.4219/jsge-2005-389

Švecová, V., Rumanová, L., \& Pavlovičová, G. (2014). Support of pupil's creative thinking in mathematical education. Procedia - Social and Behavioral Sciences, 116, 17151719. https://doi.org/10.1016/j.sbspro.2014.01.461

Yuli, T., \& Siswono, E. (2018). Pembelajaran Matematika Berbasis Pengajuan dan Pemecahan Masalah Fokus pada Berfikir Kritis dan Berfikir Kreatif. Bandung. PT. Remaja Rosdakarya. 